\title{
IMPLEMENTASI PENDIDIKAN KARAKTER \\ MELALUI FARMING GARDENING PROJECT \\ PADA ANAK USIA TAMAN KANAK-KANAK
}

\author{
Oleh: \\ Siti Khosiah \\ UNIVERSITAS SULTAN AGENG TIRTAYASA \\ skhosiah@yahoo.co.id
}

\begin{abstract}
Abstrak
Pendidikan karakter penting ditanamkan pada anak usia Taman Kanak-kanak mengingat pada usia ini anak berada pada fase imitasi yang tinggi, sehingga segala apa yang dilihat dan didengar akan ditiru. Pemberian contoh saja ternyata saat ini dipandang tidak lagi efektif, sehingga diperlukan suatu strategi komprehensif yang mampu mengaplikasikan berbagai karakter positif. Melalui kegiatan farming gardening project yang bersifat sosial, pendidikan karakter tentu akan mudah diimplementasikan oleh anak. Dengan demikian diharapkan seluruh aktifitas yang mampu menstimulasi perilaku positif dapat terus-menerus dilakukan, terarah dan terkontrol yang pada akhirnya dapat menjadi pembiasaan dalam kehidupan sehari-hari.
\end{abstract}

Keywords: Anak usia TK, pendidikan karakter, farming gardening project

\section{A. PENDAHULUAN}

\section{Latar Belakang}

Penelitian ini bertolak dari penelitian eksperimen yang telah dilakukan sebelumnya oleh peneliti tentang dampak farming gardening project terhadap perilaku sosial-emosional anak usia TK B di Ar-Rahman Islamic School Cinere Depok pada tahun 2009. Rendahnya perilaku sosial-emosional anak TK B dalam bekerja sama, tolong-menolong, berbagi, mandiri, percaya diri dan kontrol diri dapat diatasi oleh guru melalui farming gardening project. Farming gardening project atau yang sering disebut sebagai kegiatan proyek berkebun adalah kegiatan berkebun yang dilakukan secara berkelompok sebagai wahana dalam menstimulasi perilaku sosial-emosional anak. Model operasional farming gardening project ini didukung dengan miniatur alam sekitar dan bahan-bahan praktis yang digunakan setiap hari oleh orang dewasa, sehingga kegiatan belajar menjadi menyenangkan karena dilakukan sambil bermain. Bagi anak bermain sangatlah mengasyikkan, terlebih mereka yang tidak mampu duduk berjam-jam dengan tenang dan berlama-lama memusatkan perhatian.

Farming gardening project merupakan kegiatan belajar sekaligus bertindak, di mana anak diberikan kesempatan untuk mengalami penerapan topik dan isi materi yang dipelajari 
dalam situasi kehidupan sesungguhnya. Belajar berkebun dengan bersumber langsung pada lingkungan alam sekitar akan memberikan pengalaman nyata kepada anak. Dengan melihat dan mengalami secara langsung, bagaimana tanaman tumbuh hingga menghasilkan panen serta memberikan manfaat bagi makhluk hidup lainnya akan membuat anak peduli dan menghargai lingkungan dengan baik, mandiri, bertanggung jawab, kerja sama, kesalingtergantungan dan ada kemauan untuk melakukan dan bertindak yang pada gilirannya akan menumbuhkan kesadaran untuk memelihara lingkungan sejak dini.

Proyek berkebun di luar kelas menghadapkan anak pada cara penemuan dan memungkinkan mereka untuk menjadi kreatif dalam bertukar pendapat tentang penemuannya dengan teman sebaya, memiliki keterlibatan yang tinggi dengan pekerjaannya serta memiliki motivasi yang tinggi dalam menyelesaikan pekerjaan. Proyek berkebun secara alami mendorong interaksi diantara sesama anak dan orang dewasa. Dengan interaksi ini, maka sikap kerja sama, tolong-menolong, empati, simpati, berbagi (sharing), disiplin dan tanggung jawab dikembangkan. Selain itu, keadaan yang berubah antara indoor dan outdoor memberikan banyak tantangan baru. Dengan tantangan baru yang dihadapkan di luar ruangan, maka sikap percaya diri dan kemandirian anak dikembangkan. Atas dasar pemikiran ini, maka farming gardening project sebagai salah satu metode pembelajaran yang dapat menjadi solusi dalam menangani perilaku sosial-emosional anak, oleh sekolah dipandang dapat pula menjadi sarana untuk menanamkan pendidikan karakter sejak dini.

Pendidikan karakter merupakan pendidikan yang melibatkan penanaman pengetahuan, kecintaan dan penanaman perilaku kebaikan yang menjadi sebuah pola/kebiasaan. Pendidikan karakter tidak lepas dari nilai-nilai dasar yang dipandang baik. Nilai-nilai pendidikan karakter yang dapat ditanamkan pada anak usia dini (0-6 tahun), mencakup empat aspek, yaitu: 1) aspek spiritual, 2) aspek personal/kepribadian, 3) aspek sosial, dan 4) aspek lingkungan. Pada pendidikan anak usia dini nilai-nilai yang dipandang sangat penting dikenalkan dan diinternalisasikan ke dalam perilaku anak mencakup: 1) kecintaan terhadap Tuhan YME, 2) kejujuran, 3) disiplin, 4) toleransi dan cinta damai, 5) percaya diri, 6) mandiri, 7) tolong menolong, kerjasama, dan gotong royong, 8) hormat dan sopan santun, 9) tanggung jawab, 10) kerja keras, 11) kepemimpinan dan keadilan, 12) kreatif, 13) rendah hati, 14) peduli lingkungan, 15) cinta bangsa dan tanah air. 
Fikrah : Journal Of Islamic Education, Vol 1 No. 2 Desember 2017

\section{B. KAJIAN LITERATUR DAN PEMBAHASAN}

\section{Anak Usia Taman Kanak-kanak}

Rentang usia antara 4 sampai dengan 6 tahun merupakan tahapan yang disebut sebagai usia prasekolah. Pada masa ini menurut Fred Ebbeck merupakan masa yang paling hebat dan sekaligus paling sibuk. ${ }^{1}$ Pada masa ini anak sudah memiliki keterampilan dan kemampuan walaupun belum sempurna. Usia Taman Kanak-kanak sering kali disebut sebagai "the golden age" atau masa emas, yang mengandung arti bahwa masa ini merupakan fase yang sangat fundamental bagi perkembangan di mana kepribadian dasar individu mulai terbentuk.

\section{Konsep Pendidikan Karakter}

a. Pengertian Pendidikan Karakter

Pendidikan karakter merupakan pendidikan yang melibatkan penanaman pengetahuan, kecintaan dan penanaman perilaku kebaikan yang menjadi sebuah pola/kebiasaan. Pendidikan karakter adalah pendidikan budi pekerti plus, yaitu yang melibatkan aspek pengetahuan (cognitive), perasaan (feeling), dan tindakan (action). Menurut Thomas Lickona, tanpa ketiga aspek ini, maka pendidikan karakter tidak akan efektif. ${ }^{2}$

Terdapat sembilan pilar karakter yang berasal dari nilai-nilai luhur universal, yaitu: pertama, karakter cinta Tuhan dan segenap ciptaan-Nya; kedua, kemandirian dan tanggungjawab; ketiga, kejujuran/amanah, diplomatis; keempat, hormat dan santun; kelima, dermawan, suka tolong-menolong dan gotong royong/kerjasama; keenam, percaya diri dan pekerja keras; ketujuh, kepemimpinan dan keadilan; kedelapan, baik dan rendah hati, dan; kesembilan, karakter toleransi, kedamaian, dan kesatuan. Kesembilan pilar karakter ini diajarkan secara sistematis dalam model pendidikan holistik menggunakan metode knowing the good, feeling the good, dan acting the good. Knowing the good bisa mudah diajarkan sebab pengetahuan bersifat kognitif saja. Setelah knowing the good harus ditumbuhkan feeling loving the good, yakni bagaimana merasakan dan mencintai kebajikan menjadi engine yang bisa membuat orang senantiasa mau berbuat sesuatu kebaikan, sehingga tumbuh kesadaran bahwa, orang mau melakukan perilaku kebajikan karena dia cinta dengan perilaku kebajikan itu. Setelah terbiasa melakukan kebajikan, maka acting the good itu berubah menjadi kebiasaan.

b. Nilai-Nilai Pendidikan Karakter Anak Usia Dini

\footnotetext{
${ }^{1}$ Masitoh, dkk. Pendekatan Belajar Aktif di Taman Kanak-Kanak. Jakarta: Depdiknas. hlm. 7.

${ }^{2}$ Suyanto. Urgensi Pendidikan Karakter. Ditjen Pendas Kemendiknas. hlm. 23.

101 Fikrah : P-ISSN : 2599-1671, E-ISSN : 2599-168X
} 
Nilai-nilai pendidikan karakter yang dapat ditanamkan pada anak usia dini (0-6 tahun), mencakup empat aspek, yaitu: 1) aspek spiritual, 2) aspek personal/kepribadian, 3) aspek sosial, dan 4) aspek lingkungan.

Pendidikan karakter tidak lepas dari nilai-nilai dasar yang dipandang baik. Pada pendidikan anak usia dini nilai-nilai yang dipandang sangat penting dikenalkan dan diinternalisasikan ke dalam perilaku mereka mencakup: 1) kecintaan terhadap Tuhan YME, 2) kejujuran, 3) disiplin, 4) toleransi dan cinta damai, 5) percaya diri, 6) mandiri, 7), tolong menolong, kerjasama, dan gotong royong, 8) hormat dan sopan santun, 9), tanggung jawab, 10) kerja keras, 11) kepemimpinan dan keadilan, 12) kreatif, 13) rendah hati, 14) peduli lingkungan, cinta bangsa dan tanah air.

\section{c. Prinsip-Prinsip Pendidikan Karakter Anak Usia Dini}

Ada tujuh prinsip pendidikan karakter yang harus dilaksanakan oleh pendidik dan lembaga PAUD, yaitu: 1) melalui contoh dan keteladanan, 2) dilakukan secara berkelanjutan, 3) menyeluruh, terintegrasi dalam seluruh aspek perkembangan, 4) menciptakan suasana kasih sayang 5) aktif memotivasi anak, 6) melibatkan pendidik dan tenaga kependidikan, orang tua, dan masyarakat, 7) adanya penilaian.

\section{Farming Gardening Project}

a. Pengertian Farming Gardening Project

Project atau yang biasa disebut metode proyek menurut Syaiful Bahri Djamarah adalah suatu cara mengajar yang memberikan kesempatan kepada anak didik untuk menggunakan unit-unit kehidupan sehari-hari sebagai bahan pelajarannya dan bertujuan untuk menarik minat belajar anak. ${ }^{3}$ Masitoh et al. mengemukakan bahwa metode proyek merupakan salah satu bentuk pembelajaran yang menghadapkan anak pada persoalan seharihari yang ada dan harus dipecahkan baik secara individu maupun berkelompok. ${ }^{4}$ Sofa menjelaskan bahwa metode proyek adalah suatu jenis kegiatan memecahkan masalah yang dilakukan secara perorangan atau kelompok kecil serta menghasilkan produk. ${ }^{5}$ Sejalan dengan itu, Blank 1997; Dickinson et al., 1998; Harwell, 1997 berpendapat bahwa pembelajaran berbasis proyek adalah suatu strategi atau model pembelajaran autentik di mana

\footnotetext{
${ }^{3}$ Syaiful Bahri Djamarah.Guru dan Anak Didik dalam Interaksi Edukatif. Jakarta: PT RinekaCipta.hlm. 194.

${ }^{4}$ Masitoh, et al., Op. Cit., hlm. 200.

${ }^{5}$ Thom, Markham. (2003). Project Based Learning Handbookfor Middle and High School Teachers. [Online].Tersedia:http://www.amazon.com/Project-Based-Learning-Handbook-

StandardsFocused/dp/0974034304\#reader.html [23 Desember 2008]
} 
anak merencanakan, menerapkan dan mengevaluasi proyek yang merupakan aplikasi dunia nyata di luar kelas.

Pengertian farming gardening menurut The American Heritage ${ }^{\circledR}$ Dictionary of the English Language (2000) adalah sebagai berikut:

1. Farm berarti: a) suatu bidang tanah yang diolah dengan tujuan mendapatkan hasil pertanian, b) suatu bidang tanah yang disiapkan untuk meningkatkan dan mengembangbiakkan ternak lokal, c) suatu areal air yang disiapkan untuk meningkatkan dan mengembangbiakkan atau menghasilkan hewan air tertentu, seperti: ikan air tawar, tiram. Sedangkan farming berarti mengolah atau menghasilkan panen.

2. Garden memiliki makna sebagai: a) suatu bidang tanah yang digunakan untuk menanam bunga, sayur mayur, buah-buahan dan tanaman apotek hidup, b) sebidang tanah yang ditanami bunga, pepohonan, tanaman hias dan digunakan untuk rekreasi atau hiasan. Garden sering juga digunakan untuk banyak makna, seperti: kebun umum atau kebun pertanian, c) pekarangan atau halaman penuh rumput, e) daerah yang diolah dengan baik atau subur.

Senada dengan pengertian di atas, gardened memiliki arti, seperti: 1) mengolah sebidang tanah sebagai kebun, 2) menyiapkan suatu taman

Ungkapan lain dari pengertian gardening adalah: 1) menanami atau merawat kebun, 2) bekerja sebagai pe-kebun. Makna yang lain dari gardens, adalah: 1) mengenai kepantasan atau untuk digunakan di kebun, 2) disediakan dengan daerah terbuka atau tumbuhan hijau, 3) beragam kebun.

Berdasarkan uraian-uraian di atas, maka dapat dipahami bahwa farming gardening project adalah suatu kegiatan proyek bertani, berkebun, bertaman atau beternak yang dilakukan secara individu maupun berkelompok dengan memanfaatkan sebidang tanah untuk diolah dan hasil panennya dipresentasikan.

Pengertian farming gardening project yang digunakan dalam penelitian ini adalah suatu kegiatan proyek berkebun yang dilakukan secara berkelompok sebagai wahana untuk menstimulasi 14 karakter pada anak usia TK.

\section{b. Tujuan dan Prinsip Farming Gardening Project}

Hal penting yang menjadi perhatian utama dalam merencanakan sebuah proyek adalah menetapkan tujuan. Tujuan sebagai pedoman untuk merancang prosedur pelaksanaan proyek membutuhkan kemampuan guru dalam mengaplikasikan pengetahuannya tentang perkembangan dan belajar anak secara baik serta memahami teknik pembelajaran yang 
efektif.s Untuk menghasilkan pembelajaran yang efektif, maka anak harus terlibat secara bermakna dalam suatu kerja sama melalui interaksi dengan anak lain dan tugas-tugas tertentu. Kearsley dan Shneiderman menyatakan bahwa ada tiga hal yang penting dalam mendukung keterlibatan anak, yaitu menekankan pada kerja sama, berbasis penelitian dan berfokus pada hal-hal yang bersifat non akademik. Menurut Kearsley dan Shneiderman (1999), tiga hal ini diduga dapat menghasilkan pembelajaran yang kreatif, bermakna dan autentik. ${ }^{6}$

Dari ulasan di atas dapat dijelaskan bahwa sebelum kegiatan proyek dimulai guru hendaknya menetapkan tujuan dan mengidentifikasi berbagai kemampuan yang akan dipelajari anak. Herman et al. mengidentifikasi lima kemampuan yang menjadi pertimbangan ketika menentukan tujuan sebuah proyek, diantaranya adalah: 1) kemampuan kognitif apa yang akan dikembangkan pada anak, 2) kemampuan sosial dan moral apa yang akan dikembangkan pada anak, 3) kemampuan metakognitif apa yang akan dikembangkan pada anak, 4) tipe problem apa yang akan diselesaikan oleh anak, 5) rencana apa yang akan dipraktekkan oleh anak. ${ }^{7}$

Tujuan farming menurut National Farm to School, yaitu: 1) meningkatkan kesehatan dan gizi anak, 2) memperluas pemahaman anak mengenai makanan, dan 3) membantu guru untuk menemukan standar pembelajaran sains dan ekologi.

Lebih spesifik Subramaniam et al. menjelaskan tujuan gardening, yaitu: 1) untuk mendukung pembelajaran, khususnya di bidang sains dan matematika, 2) menjadikan pembelajaran lebih menyenangkan, menantang, memiliki dampak emosional dan estetika serta mengapresiasi untuk belajar, 3) dasar untuk mengajarkan keterampilan dan kompetensi kejuruan, 4) mengajarkan tentang produksi makanan, 5) mengajarkan keaksaraan ekologis dan pendidikan lingkungan, 6) mengajarkan pembangunan berkelanjutan, 7) memproduksi makanan dan komoditas lainnya untuk konsumsi pribadi dan perdagangan, 8) meningkatkan gizi, kesehatan dan diet.

Sejalan dengan tujuan pembelajaran berbasis proyek, Jennifer Railsback mengemukakan bahwa hal yang utama dalam kegiatan berbasis proyek adalah memberikan kesempatan kepada anak-anak untuk menemukan kesenangan, termotivasi dan tertantang, sebab ketika kegiatan proyek berlangsung anak-anak berperan aktif dalam mengikuti seluruh proses yang direncanakan. ${ }^{8}$ Pannen menegaskan bahwa belajar yang baik adalah jika anak memperoleh tantangan yang cukup. Dalam hal ini, farming gardening project dapat

\footnotetext{
${ }^{6}$ Ibid., hlm. 5.

${ }^{7}$ Jennifer Railsback, Op. Cit., hlm. 12.

${ }^{8}$ Jennifer Railsback, Loc. Cit.

104 Fikrah : P-ISSN : 2599-1671, E-ISSN : 2599-168X
} 
Fikrah : Journal Of Islamic Education, Vol 1 No. 2 Desember 2017

memberikan tantangan yang cukup, menyenangkan dan memotifasi anak untuk mengembangkan potensinya asalkan sesuai dengan prinsip-prinsip kegiatan proyek itu sendiri, seperti: 1) sederhana, yaitu dapat dibuat dengan ukuran sedang, sehingga dapat diatur sendiri oleh anak, guru maupun orang tua, 2) mudah, yaitu cukup dengan menanam sayuran dan buah-buahan, atau sama halnya dengan beternak ayam atau kelinci, 3) dapat ditiru, yaitu anak mampu untuk meniru atau mempraktekkannya di rumah. ${ }^{9}$

Dengan demikian dapat disimpulkan bahwa tujuan dan prinsip farming gardening project adalah memberikan pemahaman kepada anak tentang kesehatan dan gizi melalui kegiatan farming gardening yang dilakukan secara mudah, sederhana dan dapat dipraktekkan dalam kehidupan sehari-hari guna mendukung program taman gizi di sekolah.

Tujuan dan prinsip farming gardening project dalam penelitian ini adalah menjadikan kegiatan proyek berkebun yang sederhana, mudah dan dapat dipraktekkan dalam kehidupan sehari-hari sebagai wahana untuk menstimulasi 14 karakter pada anak.

\section{c. Manfaat Farming Gardening Project}

Kegiatan farming gardening project memberikan banyak manfaat dalam pembelajaran, karena dalam prosesnya anak diberikan kesempatan untuk mengalami sendiri, memecahkan masalah dan menerapkan apa yang diperolehnya dalam kehidupan sehari-hari. Kegiatan berbasis proyek ini menurut Masitoh et al. dapat melatih berbagai kemampuan anak, diantaranya: 1) kemampuan untuk bersosialisasi, 2) kemampuan untuk bekerja sama, 3) kemampuan untuk tolong-menolong, 4) mengembangkan aspek moral anak, dan 5) mengembangkan disiplin anak. ${ }^{10}$

Hasil penelitian pada lima sekolah yang telah diteliti di Trøndelag Noerwegia utara dari tahun 1995-2000 menyebutkan beberapa keuntungan dari farming project, yaitu: 1) sebagai sumber pembelajaran untuk meningkatkan kemampuan sosial anak, pengalaman belajar, kemampuan mengidentifikasi dan meningkatkan komitmen di bidang ekonomi budaya yang berfokus pada pengetahuan alam, makanan dan budaya, 2) membangun hubungan pribadi anak-anak dengan makanan, 3) menjalin hubungan antara orang tua dan guru.

Secara khusus Department of Horticulture Cornell University menjelaskan bahwa gardening project memiliki manfaat: 1) meningkatkan derajat hidup anak di masa depan, 2) meningkatkan harga diri anak, rasa memiliki, tanggung jawab serta mempererat hubungan dengan anggota keluarga, 3) meningkatkan kemampuan komunikasi non verbal,

\footnotetext{
${ }^{9}$ Pannen Pannen, P. (2005). "Pengembangan E-learning: Antara Mitos dan Kenyataan". Makalah pada Seminar Nasional Teknologi Pembelajaran. Jakarta, 5-6 Desember.

${ }^{10}$ Masitoh et al.Op. Cit., hlm. 200.
}

105 Fikrah : P-ISSN : 2599-1671, E-ISSN : 2599-168X 
mengembangkan kesadaran mengenai keuntungan tata tertib, belajar berpartisipasi dalam suatu kerja sama dan membangun hubungan dengan orang dewasa, 4) meningkatkan hubungan kekeluargaan. ${ }^{11}$

Berdasarkan uraian di atas, maka dapat disimpulkan bahwa manfaat farming gardening project, yaitu: 1) menjadikan anak sejak dini sadar lingkungan, peduli dan disiplin, 2) meningkatkan kerja sama dan membangun hubungan dengan orang dewasa, 3) tanggung jawab, tolong-menolong, dan 4) mengendalikan moral di dalam situasi sosial, 5) memecahkan masalah yang dihadapi sehari-hari secara mandiri, 6) memahami diri sendiri, dan 7) meningkatkan rasa percaya diri.

Penelitian sejenis tentang pendidikan karakter diantaranya adalah:

1. "Pengembangan Model Pendidikan Karakter dengan Pendekatan Komprehensif, Terpadu dalam Pembelajaran Bahasa Indonesia, IPA, dan IPS di Sekolah Dasar”. Penelitian eksperimen ini dilakukan oleh Prof. Darmiyati Zuchdi, Ed.D.; Prof. Dr. Zuhdan Kun Prasetya; dan Dr. Muhsinatun Siasah Masruri, di empat Sekolah Dasar / Madrasah Ibtidaiyah negeri dan swasta di Kabupaten Sleman dan Kota Yogyakarta di Provinsi DIY yang bertujuan untuk menghasilkan model pendidikan karakter dengan pendekatan komprehensif, meliputi domain kognitif, afektif, dan perilaku, dengan metode inkulkasi, keteladanan, dan pengembangan habit, yang terintegrasi dalam pembelajaran bidang studi Bahasa Indonesia, IPA, dan IPS, disertai pengembangan kultur sekolah yang kondusif. Hasil penelitian menunjukkan bahwa model pendidikan karakter dengan pendekatan komprehensif, yang terintegrasi dalam pembelajaran terbukti efektif untuk meningkatkan hasil studi dan karakter peserta didik serta peningkatkan kualitas kultur sekolah. ${ }^{12}$

2. "Upaya Mewujudkan Pendidikan Karakter Bangsa Melalui Penerapan Pendekatan Pembelajaran Aktif, Kreatif, Efektif dan Menyenangkan (Pakem) dalam Kegiatan pembelajaran di Cikeusik Pandeglang”. Penelitian tindakan sekolah ini telah dilakukan Mulyana (2011) dengan tujuan untuk meningkatkan keterlaksanaan nilai pembangunan karakter bangsa dalam kegiatan pembelajaran. Mulyana menyatakan bahwa pembelajaran yang diterapkan dengan Pendekatan Pembelajaran Aktif, Kreatif, Efektif, dan

\footnotetext{
${ }^{11}$ Norway. (2008). The Farm as a Pedagogical Resource Health and Learning from Farm Activities for School $\begin{array}{llll}\text { Children in Norway. [Online]. Tersedia: } & \text { [ }\end{array}$ http://www.livinglearning.org/PDF\%20documents/The\%20Farm\%20as\%20a\%20Pedagogical\%20Resource\%5 B1\%5D.pdf [7 Januari 2009]

${ }^{12}$ Zuchdi, Darmiyati. dkk. Pendidikan Karakter Melalui Pengembangan Keterampilan Hidup dalam Kurikulum Persekolahan. Laporan Penelitian Hibah Pasca 2005- 2006. Yogyakarta: Lembaga Penelitian UNY.
}

106 |Fikrah : P-ISSN : 2599-1671, E-ISSN : 2599-168X 
Fikrah : Journal Of Islamic Education, Vol 1 No. 2 Desember 2017

Menyenangkan (PAKEM) di SMPN 2 Cikeusik dapat berjalan efektif, sehingga keterlaksanaan nilai-nilai Pendidikan Karakter Bangsa dapat meningkat.” 13

Dari hasil penelitian sejenis yang pernah diteliti, belum diperoleh informasi tentang penelitian implementasi pendidikan karakter melalui farming gardening project pada anak usia Taman Kanak-kanak. Dengan demikian, permasalahan ini layak untuk diteliti.

\section{METODE PENELITIAN}

Penelitian ini menggunakan studi kualitatif naturalistik. Studi kualitatif naturalistik merupakan penelitian yang menerapkan dependabilitas atau yang sering disebut dengan realibilitas dan konfirmabilitas berkaitan dengan masalah kebenaran penelitian naturalistik atau objektivitas, dimana sesuatu itu objektif atau tidak bergantung pada persetujuan beberapa orang terhadap pandangan, pendapat dan penemuan seseorang. Hal ini dilakukan melalui proses audit trail.

Langkah awal penelitian dimulai dengan melakukan survey untuk mengumpulkan informasi yang dibutuhkan melalui komunikasi langsung dengan pihak kepala sekolah yang kemudian diikuti dengan penyusunan desain penelitian berdasarkan pada data temuan di lapangan. Selanjutnya kepala sekolah menginformasikan kepada guru untuk kemudian dilaksanakan oleh peneliti sesuai dengan kesepakatan. Prosedur pengumpulan data dalam penelitian ini, meliputi: wawancara, observasi dan dokumentasi dengan aktifitas analisis data yang meliputi: reduksi data (data reduction), penyajian data (data display) serta penarikan kesimpulan dan verifikasi (conclusion drawing / verification). Dengan mengkonfirmasi makna setiap data yang diperoleh dengan menggunakan satu cara atau lebih, diharapkan peneliti memperoleh informasi yang dapat digunakan untuk mendukung tercapainya tujuan penelitian. Penarikan kesimpulan penelitian kualitatif diharapkan merupakan temuan baru yang belum pernah ada.

\section{HASIL ANALISIS}

Pada bab ini akan diuraikan secara keseluruhan temuan hasil penelitian tentang implementasi pendidikan karakter melalui farming gardening project pada anak usia TK B di KB-TK Ar-Rahman Islamic School Cinere Depok tahun 2013-2014, dimana tema kegiatan proyek berkebun pada semester ini adalah menanam sayur Bayam.

Penanaman nilai-nilai karakter yang diberikan melalui kegiatan farming gardening project perlu diciptakan dalam proses penanaman nilai-nilai karakter. Penanaman nilai karakter pada anak bukan hanya sekadar mengharapkan kepatuhan, tetapi harus disadari dan

\footnotetext{
${ }^{13}$ Mulyana, Pendekatan Pembelajaran PAIKEM.

107 Fikrah : P-ISSN : 2599-1671, E-ISSN : 2599-168X
} 
diyakini oleh anak sehingga mereka merasa bahwa nilai tersebut memang benar dan bermanfaat untuk dirinya dan lingkungannya. Dengan demikian mereka termotivasi dari dalam diri untuk menerapkan dan terus memelihara nilai tersebut dalam kehidupan sehariharinya. Penerapan pendidikan karakter bagi anak usia TK B dilakukan melalui tahapantahapan sebagai berikut:

\section{Perencanaan}

Perencanaan pendidikan karakter melalui farming gardening project dikembangkan dengan memperhatikan hal-hal berikut: a) mengenal dan memahami anak seutuhnya sesuai dengan tahapan perkembangan dan karakteristiknya, b) nilai-nilai pendidikan karakter diterapkan menyatu dengan kegiatan inti proses pembelajaran yang dilakukan dengan cara: 1) memilih nilai-nilai karakter yang sesuai dengan kegiatan pembelajaran, dan 2) menentukan indikator perkembangan nilai-nilai karakter, sesuai dengan tahap perkembangan anak, c) menentukan jenis dan tahapan kegiatan yang akan dilaksanakan.

Tahapan kegiatan farming gardening project yang dilakukan dalam penelitian ini adalah:

a) Tahap Persiapan

1) Pengantar

Guru memberikan informasi atau penjelasan singkat tentang proyek tanaman sayur yang akan dilakukan berkenaan dengan prosedur jenis kegiatan. Kegiatan opening dilakukan sebelum anak berada di area berkebun. Tujuannya adalah memberikan pemahaman konsep dan nilai karakter yang akan dicapai.

2) Memilih Tema

Guru memberikan kesempatan kepada anak-anak untuk berpartisipasi dalam memilih tema karakter yang akan dibahas. Dengan partisipasi ini anak diharapkan menjadi lebih percaya diri. Selain itu, guru dapat mengarahkan anak pada tema yang akan dibahas pada hari itu, yaitu dengan melakukan tanya jawab berkaitan dengan karakterkarakter positif sekaligus proyek tanaman sayur. Pada tahap pemilihan tema, hasil tanya jawab dan diskusi menyepakati bahwa anak-anak akan menanam sayur Bayam. Hal ini didasari oleh pemikiran bahwa sayur Bayar mudah ditanam dan dipanen dalam waktu yang tidak terlalu lama. Agar mudah dipahami, anak-anak dengan bantuan guru dapat membuat pemetaan pikiran tentang karakter yang akan diimplementasikan sekaligus kegiatan proyek berkebun, sebagaimana gambar berikut: 
Gambar 1

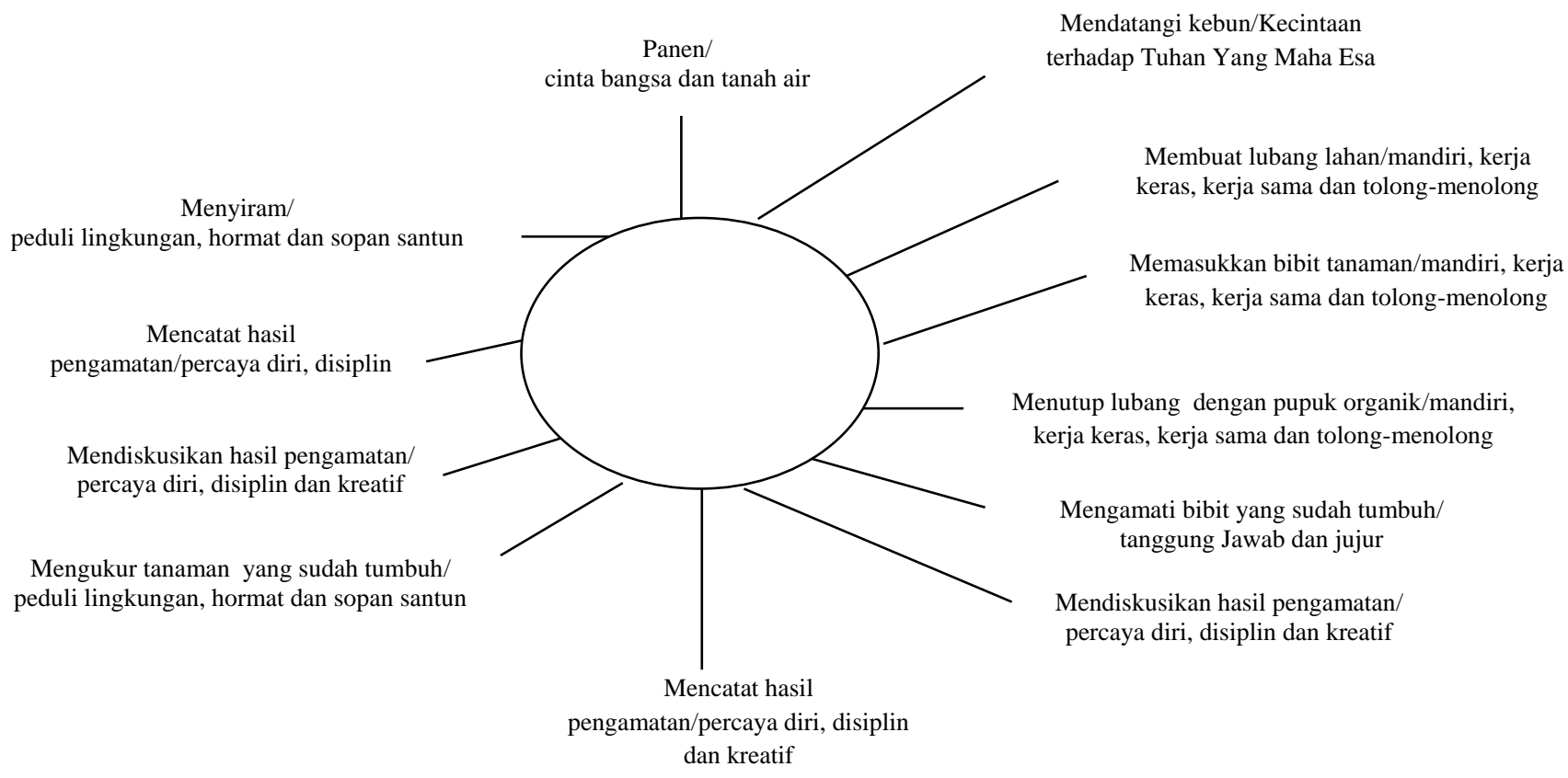

3) Mengorganisasikan Anak

Pada tahap ini guru membagi anak ke dalam beberapa kelompok. Setiap kelompok terdiri dari dua anak dan mengerjakan tugasnya masing-masing. Selanjutnya anak bekerja sama, berbagi, dan bergantian untuk menyempurnakan tugas kelompoknya. Contoh: satu anak membuat lubang lahan, dan anak lainnya memasukkan bibit tanaman, kemudian mereka bersama-sama menutup lubang tanah dengan pupuk organik.

4) Membuat Perencanaan

Dengan bantuan guru, setiap kelompok merancang kegiatan yang akan dilakukannya.

b) Tahap Pelaksanaan

1) Tahap Bekerja

Setiap kelompok melakukan pekerjaan sesuai dengan rencana yang sudah disusun sebelumnya. Guru bertindak sebagai fasilitator yang siap memberikan bantuan jika diperlukan.

2) Hasil

Setiap kelompok menyelesaikan pekerjaan sesuai dengan waktu yang telah ditentukan dan memperlihatkan hasil pekerjaannya. 
c) Tahap Evaluasi

Evaluasi dilakukan guru untuk membantu anak mengemukakan permasalahan yang dihadapi ketika melakukan kegiatan proyek. Guru mereviuw apa yang telah dilakukan anak dengan memberikan pujian kepada anak.

\section{Pelaksanaan}

Pelaksanaan nilai-nilai karakter melalui farming gardening project dilakukan dengan memperhatikan komponen-komponen berikut:

a) Situasi Atau Masalah

Situasi atau masalah merupakan dua hal yang akan dijadikan topik dalam kegiatan farming gardening project. Misal: anak-anak sulit untuk bertanggung jawab mengembalikan peralatan yang telah dipakai ke tempatnya semula.

b) Target

Guru menjelaskan secara ringkas mengenai tujuan akhir yang harus dicapai dalam kegiatan farming gardening project. Misal: anak-anak dapat bertanggung jawab terhadap tanaman sayur Bayam dalam kegiatan farming gardening project. Bertanggung jawab terhadap sayur Bayam merupakan cara untuk melatih anak-anak agar nantinya dapat bertanggung jawab terhadap apapun yang dibebankan temasuk mengembalikan peralatan pada tempatnya.

c) Aturan

Guru dan anak-anak membuat aturan bersama.

d) Mengorganisasikan Anak

Guru membagi anak ke dalam beberapa kelompok. Setiap kelompok terdiri dari dua anak dan mengerjakan tugasnya masing-masing. Selanjutnya anak bekerja sama, berbagi, dan bergantian untuk menyempurnakan tugas kelompoknya.

e) Penilaian

Mengevaluasi apa yang telah dicapai anak, baik dalam proses pembelajaran maupun produk akhir.

Berikut implementasi 14 karakter melalui farming gardening project, diantaranya:

a) Kecintaan terhadap Tuhan Yang Maha Esa

1) Guru menggali pemahaman anak untuk tiap-tiap nilai karakter. Kegiatan ini dilakukan melalui dialog yang dipandu oleh guru. Misalnya untuk tema karakter kecintaan terhadap Tuhan Yang Maha Esa, guru mengajukan pertanyaan terbuka tentang kecintaan terhadap

110 Fikrah : P-ISSN : 2599-1671, E-ISSN : 2599-168X 
Tuhan Yang Maha Esa dalam menciptakan makhluk hidup. Contoh pertanyaan guru, "Siapakah yang menciptakan makhluk hidup di alam semesta ini?", "Bagaimana cara kita agar Tuhan cinta kepada kita?" Setiap anak memberi jawaban yang berbeda. Semua pendapat anak dihargai guru karena itu mencerminkan pemahaman mereka.

2) Membangun penghayatan anak dengan melibatkan emosinya untuk menyadari pentingnya menerapkan nilai karakter (kecintaan terhadap Tuhan Yang Maha Esa). Proses ini dibangun juga melalui pertanyaan terbuka dan melalui pengamatan. Misalnya setelah berdialog tentang karakter kecintaan terhadap Tuhan Yang Maha Esa, guru mulai mengajak anak-anak ke kebun sekolah untuk mengamati kebun. Guru kemudian mengajukan pertanyaan, "Mengapa kebun kita gersang?", "Bagaimana hawanya bila kebun kita gersang?", "Apa yang harus kita lakukan agar kebun kita subur sehingga Tuhan mencintai kita?"

3) Mengajak anak untuk bersama-sama melakukan nilai-nilai karakter yang telah didiskusikan. Misal: setelah anak-anak mengamati kebun, mereka terdorong melakukan karakter kecintaan terhadap Tuhan Yang Maha Esa dengan bersedia memelihara makhluk hidup lain berupa sayuran Bayam. Guru memberi kesempatan kepada anak untuk melaksanakan karakter kecintaan terhadap Tuhan Yang Maha Esa sesuai keinginan dan kemampuan anak.

4) Ketercapaian tahapan perkembangan anak didik. Dalam hal ini anak diminta untuk menceritakan kegiatan dan perasaannya setelah melakukan kegiatan. Guru memberikan penguatan dan pujian serta sentuhan kasih sayang terhadap apa yang direfleksikan anak, misalnya dengan mengatakan, "Terimakasih, sudah cinta terhadap Tuhan dengan bersedia untuk menanami kebun.”

\section{b) Mandiri, Kerja Keras, Kerja Sama dan Tolong-Menolong}

1) Guru menggali pemahaman anak untuk tiap-tiap nilai karakter. Kegiatan ini dilakukan melalui dialog yang dipandu oleh guru. Misalnya untuk tema karakter mandiri, kerja keras, kerja sama dan tolong-menolong guru mengajukan pertanyaan terbuka tentang kemandirian, kerja keras, kerja sama dan tolong-menolong. Contoh pertanyaan guru, "Mengapa kita harus menyelesaikan tugas sendiri tanpa bantuan orang lain?", "Bagaimana cara kita agar cepat menyelesaikan tugas kelompok?" Setiap anak dapat memberi jawaban yang berbeda. Semua pendapat anak dihargai guru karena itu mencerminkan pemahaman mereka.

111 Fikrah : P-ISSN : 2599-1671, E-ISSN : 2599-168X 
2) Membangun penghayatan anak dengan melibatkan emosinya untuk menyadari pentingnya menerapkan nilai karakter (mandiri, kerja keras, kerja sama dan tolongmenolong). Proses ini dibangun juga melalui pertanyaan terbuka dan melalui pengamatan. Misalnya setelah berdialog tentang karakter kemandirian, kerja keras, kerja sama dan tolong-menolong, guru mulai mengajak anak-anak ke kebun sekolah untuk mengamati kebunnya yang masih gersang. Guru kemudian mengajukan pertanyaan, "Mengapa kebun kita masih gersang?", "Bagaimana caranya agar kebun kita tampak hijau?", “Siapa yang akan mencoba kemampuannya sendiri untuk melubangi lahan kebun, menanam benih atau memberi pupuk organik?", "Bagaimana caranya menyelesaikan pekerjaan melubangi lahan kebun, menanam benih dan memberi pupuk organik dengan cepat?”.

3) Mengajak anak untuk bersama-sama melakukan nilai-nilai karakter yang telah didiskusikan. Misal: setelah anak-anak mengamati kebun yang gersang, mereka terdorong melakukan karakter mandiri, kerja keras, kerja sama dan tolong-menolong dalam menanam sayur Bayam dan guru memberi kesempatan kepada anak untuk melaksanakan karakter tersebut sesuai keinginan dan kemampuan anak.

4) Ketercapaian tahapan perkembangan anak didik. Dalam hal ini anak diminta untuk menceritakan kegiatan dan perasaannya setelah melakukan kegiatan. Guru memberikan penguatan dan pujian serta sentuhan kasih sayang terhadap apa yang direfleksikan anak, misalnya dengan mengatakan, "Terimakasih, sudah bekerja mandiri, kerja keras, kerja sama dan tolong-menolong untuk menanam sayur Bayam.”

\section{c) Tanggung Jawab dan Jujur}

1) Guru menggali pemahaman anak untuk tiap-tiap nilai karakter. Kegiatan ini dilakukan melalui dialog yang dipandu oleh guru. Misalnya untuk tema karakter tanggung jawab dan jujur guru mengajukan pertanyaan terbuka tentang tanggung jawab dalam memelihara sayuran Bayam. Contoh pertanyaan guru, "Mengapa kita harus bertanggung jawab dengan tugas yang telah diberikan?", "Bagaimana cara kita bertanggung jawab terhadap tugas yang telah diberikan?" Setiap anak memberi jawaban yang berbeda. Semua pendapat anak dihargai guru karena itu mencerminkan pemahaman mereka.

2) Membangun penghayatan anak dengan melibatkan emosinya untuk menyadari pentingnya menerapkan nilai karakter (bertanggung jawab dan jujur). Proses ini dibangun juga melalui pertanyaan terbuka dan melalui pengamatan. Misalnya setelah berdialog tentang karakter tanggung jawab dan jujur, guru mulai mengajak anak-anak ke 
kebun sekolah untuk mengamati sayuran Bayamnya. Guru kemudian mengajukan pertanyaan, "Mengapa ada benih yang sudah tumbuh dan belum tumbuh?", "Bagaimana rasanya bila kita menjadi benih yang belum tumbuh?", "Apa yang harus kita lakukan agar benih yang ditanam cepat tumbuh?"

3) Mengajak anak untuk bersama-sama melakukan nilai-nilai karakter yang telah didiskusikan. Misal: setelah anak-anak mengamati sayuran Bayamnya, mereka terdorong melakukan karakter tanggung jawab dan jujur terhadap pemeliharaan sayuran Bayam dan guru memberi kesempatan kepada anak untuk melaksanakan karakter tersebut sesuai keinginan dan kemampuan anak.

4) Ketercapaian tahapan perkembangan anak didik. Dalam hal ini anak diminta untuk menceritakan kegiatan dan perasaannya setelah melakukan kegiatan. Guru memberikan penguatan dan pujian serta sentuhan kasih sayang terhadap apa yang direfleksikan anak, misalnya dengan mengatakan, "Terimakasih, sudah bertanggung jawab dan jujur untuk mengamati sayuran Bayam.”

\section{d) Percaya Diri, Disiplin dan Kreatif}

1) Guru menggali pemahaman anak untuk tiap-tiap nilai karakter. Kegiatan ini dilakukan melalui dialog yang dipandu oleh guru. Misalnya untuk tema karakter percaya diri, disiplin dan kreatif, guru mengajukan pertanyaan terbuka tentang percaya diri, disiplin dan kreatif dalam memelihara sayur Bayam. Contoh pertanyaan guru, "Mengapa kita harus berani mengerjakan tugasnya sendiri-sendiri?", "Mengapa kita harus rutin mengerjakan tugas yang telah diberikan?", "Mengapa kita harus kreatif dalam mengerjakan tugas yang telah diberikan?" Setiap anak memberi jawaban yang berbeda. Semua pendapat anak dihargai guru karena itu mencerminkan pemahaman mereka.

2) Membangun penghayatan anak dengan melibatkan emosinya untuk menyadari pentingnya menerapkan nilai karakter (percaya diri, disiplin dan kreatif). Proses ini dibangun juga melalui pertanyaan terbuka dan melalui pengamatan. Misalnya setelah berdialog tentang karakter percaya diri, disiplin dan kreatif, guru mulai mengajak anakanak ke kebun sekolah untuk mendiskusikan hasil pengamatan terhadap sayuran Bayam. Guru kemudian mengajukan pertanyaan,"Mengapa ada sayuran Bayam yang layu dan segar?", "Bagaimana rasanya bila kita menjadi sayuran Bayam yang layu tersebut?", ”Apa yang harus kita lakukan agar sayuran Bayam tidak layu?”, “

3) Mengajak anak untuk bersama-sama melakukan nilai-nilai karakter yang telah didiskusikan. Misal: setelah anak-anak mengamati sayuran Bayamnya, mereka terdorong 
melakukan karakter percaya diri, disiplin dan kreatif dalam memelihara sayuran Bayam dan guru memberi kesempatan kepada anak untuk melaksanakan karakter tersebut sesuai keinginan dan kemampuan anak.

4) Ketercapaian tahapan perkembangan anak didik. Dalam hal ini anak diminta untuk menceritakan kegiatan dan perasaannya setelah melakukan kegiatan. Guru memberikan penguatan dan pujian serta sentuhan kasih sayang terhadap apa yang direfleksikan anak, misalnya dengan mengatakan, "Terimakasih, sudah percaya diri, disiplin dan kreatif dalam menangani sayuran Bayam yang layu.”

\section{e) Peduli Lingkungan, Hormat dan Sopan Santun}

1) Guru menggali pemahaman anak untuk tiap-tiap nilai karakter. Kegiatan ini dilakukan melalui dialog yang dipandu oleh guru. Misalnya untuk tema karakter peduli lingkungan, hormat dan sopan santun, guru mengajukan pertanyaan terbuka tentang peduli lingkungan, hormat dan sopan santun. Contoh pertanyaan guru, "Mengapa kita harus peduli terhadap lingkungan sekitar?", ”Bagaimana cara kita menghormati lingkungan sekitar agar aman dan nyaman?" Setiap anak memberi jawaban yang berbeda. Semua pendapat anak dihargai guru karena itu mencerminkan pemahaman mereka.

2) Membangun penghayatan anak dengan melibatkan emosinya untuk menyadari pentingnya menerapkan nilai karakter (peduli lingkungan, hormat dan sopan santun). Proses ini dibangun juga melalui pertanyaan terbuka dan melalui pengamatan. Misalnya setelah berdialog tentang karakter peduli lingkungan, hormat dan sopan santun, guru mulai mengajak anak-anak ke kebun sekolah untuk mengamati sayuran Bayam. Guru kemudian mengajukan pertanyaan, "Mengapa ada sayuran Bayam yang tinggi dan pendek?", "Bagaimana rasanya bila kita menjadi sayuran Bayam yang lambat tumbuhnya?", "Apa yang harus kita lakukan agar sayuran Bayam lekas tinggi dan segera dipanen?".

3) Mengajak anak untuk bersama-sama melakukan nilai-nilai karakter yang telah didiskusikan. Misal: setelah anak-anak mengamati sayuran Bayamnya, mereka terdorong melakukan karakter peduli lingkungan, hormat dan sopan santun terhadap sayur Bayam dan guru memberi kesempatan kepada anak untuk melaksanakan karakter tersebut sesuai keinginan dan kemampuan anak.

4) Ketercapaian tahapan perkembangan anak didik. Dalam hal ini anak diminta untuk menceritakan kegiatan dan perasaannya setelah melakukan kegiatan. Guru memberikan penguatan dan pujian serta sentuhan kasih sayang terhadap apa yang direfleksikan anak,

114 Fikrah : P-ISSN : 2599-1671, E-ISSN : 2599-168X 
Fikrah : Journal Of Islamic Education, Vol 1 No. 2 Desember 2017

misalnya dengan mengatakan, "Terimakasih, sudah peduli, hormat dan sopan santun terhadap sayur Bayam."

\section{f) Cinta Tanah Air dan Bangsa}

1) Guru menggali pemahaman anak untuk tiap-tiap nilai karakter. Kegiatan ini dilakukan melalui dialog yang dipandu oleh guru. Misalnya untuk tema karakter cinta tanah air dan bangsa, guru mengajukan pertanyaan terbuka tentang cinta tanah air dan bangsa. Contoh pertanyaan guru, “Mengapa kita harus cinta tanah air?”, "Bagaimana cara kita mencintai tanah air?" Setiap anak memberi jawaban yang berbeda. Semua pendapat anak dihargai guru karena itu mencerminkan pemahaman mereka.

2) Membangun penghayatan anak dengan melibatkan emosinya untuk menyadari pentingnya menerapkan nilai karakter (cinta tanah air dan bangsa). Proses ini dibangun juga melalui pertanyaan terbuka dan melalui pengamatan. Misalnya setelah berdialog tentang karakter cinta tanah air dan bangsa, guru mulai mengajak anak-anak ke kebun sekolah untuk memanen sayur Bayam. Guru kemudian mengajukan pertanyaan, "Mengapa sayur Bayam kita lambat tumbuhnya?", "Bagaimana rasanya bila kita menjadi sayuran Bayam yang lambat tumbuhnya?", "Apa yang harus kita lakukan agar sayuran Bayam lekas tinggi dan segera dipanen?”.

3) Mengajak anak untuk bersama-sama melakukan nilai-nilai karakter yang telah didiskusikan. Misal: setelah anak-anak mengamati sayuran Bayamnya, mereka terdorong melakukan karakter peduli lingkungan, hormat dan sopan santun terhadap sayur Bayam dan guru memberi kesempatan kepada anak untuk melaksanakan karakter tersebut sesuai keinginan dan kemampuan anak.

4) Ketercapaian tahapan perkembangan anak didik. Dalam hal ini anak diminta untuk menceritakan kegiatan dan perasaannya setelah melakukan kegiatan. Guru memberikan penguatan dan pujian serta sentuhan kasih sayang terhadap apa yang direfleksikan anak, misalnya dengan mengatakan, "Terimakasih, sudah peduli, hormat dan sopan santun terhadap sayur Bayam.”

\section{Penilaian}

Tahap penilaian mencakup tujuan penilaian, prinsip penilaian, lingkup penilaian, cara penilaian, instrumen penilaian, dan pengembangan indikator.

a. Tujuan Penilaian 
Tujuan penilaian adalah untuk mengetahui sejauh mana perubahan sikap dan perilaku anak-anak setelah mengikuti kegiatan farming gardening project yang sarat dengan nilai-nilai karakter. Kegiatan penilaian dilakukan oleh pendidik secara berkesinambungan dan terus menerus agar perubahan sikap dan perilaku anak dapat dilihat secara utuh.

b. Prinsip Penilaian

Dalam melakukan penilaian keberhasilan pendidikan karakter, guru memperhatikan beberapa prinsip, yaitu: 1) menyeluruh, artinya penilaian mencakup aspek proses dan hasil penanaman nilai-nilai karakter yang secara bertahap menggambarkan perubahan sikap dan perilaku anak, 2) berkesinambungan, artinya penilaian dilakukan secara berencana, bertahap dan terus menerus untuk memperoleh gambaran menyeluruh terhadap hasil penanaman nilainilai karakter, 3) obyektif, sesuai dengan apa yang dialami atau terjadi pada diri anak dengan memperhatikan perbedaan keunikan masing-masing individu, 4) mendidik, artinya hasil penilaian digunakan untuk membina dan mendorong anak-anak dalam meningkatkan kemampuan atau mengembangkan sikap dan perilaku sesuai dengan nilai-nilai karakter, 5) kebermaknaan, artinya hasil penilaian bermakna baik bagi pendidik, pengasuh, orang tua, anak didik dan pihak lain.

c. Teknik dan Instrumen Penilaian

Penilaian penanaman nilai-nilai karakter dilakukan melalui kegiatan: 1) pengamatan, yaitu suatu cara untuk mengetahui perkembangan atau perubahan sikap dan perilaku anak dalam kehidupan sehari-hari, khususnya selama berada di sekolah dengan cara melihat secara langsung. Untuk mempermudah melakukan pengamatan, pendidik menggunakan instrumen pengamatan dalam bentuk check list $(\sqrt{ }), 2$ ) unjuk kerja, merupakan penilaian yang dilakukan dengan mengamati kegiatan anak melakukan sesuatu dalam menerapkan nilai-nilai karakter, 3) pencatatan anekdot (anecdotal record), yaitu menggambarkan peristiwa-peristiwa penting atau unik yang terjadi sehari-hari, 4) percakapan atau dialog, yaitu menanyakan kepada anak secara langsung tentang kegiatan farming gardening project. Pendidik mewancarai anak-anak ketika beraktivitas dengan melontarkan pertanyaan secara spontan. Simpulan hasil wawancara digunakan pendidik untuk memberikan nilai pada anak didik.

\section{E. KESIMPULAN DAN REKOMENDASI}

\section{Kesimpulan}

a. Perencanaan pendidikan karakter melalui farming gardening project di Ar-Rahman Islamic School Cinere Depok dilakukan guru dengan beberapa tahapan dari persiapan mengenai prosedur kegiatan proyek, pengkondisian kelompok anak hingga membuat

116 |Fikrah : P-ISSN : 2599-1671, E-ISSN : 2599-168X 
Fikrah : Journal Of Islamic Education, Vol 1 No. 2 Desember 2017

mind maping bersama anak sebagai acuan dalam mengimplementasikan pendidikan karakter ke dalam kegiatan proyek berkebun.

b. Pelaksanaan empat belas nilai-nilai karakter melalui farming gardening project dilakukan guru dengan kegiatan mengamati, berdialog untuk menumbuhkan rasa empati dan peduli serta mempraktekkan langsung hasil dari dialog dalam kegiatan.

c. Tahap penilaian pendidikan karakter dilakukan guru melalui kegiatan pengamatan, unjuk kerja, pencatatan asnekdot (anecdotal record), dan percakapan atau dialog. Pengamatan dilakukan dengan cara mengamati perilaku/karakter yang ditunjukkan anak ketika sedang melakukan kegiatan proyek berkebun. Unjuk kerja dilakukan dengan cara memberikan pekerjaan pada anak untuk melakukan kegiatan tertentu yang berkaitan dengan pendidikan karakter dalam kegiatan proyek berkebun. Pencatatan anekdot dilakukan dengan cara mencatat kejadian spontanitas terhadap karakter yang ditunjukkan anak, sedang percakapan/dialog dilakukan dengan wawancara sederhana antara guru dan anak secara fleksibel.

\section{Rekomendasi}

Pada dasarnya menanamkan nilai-nilai karakter sejak usia dini merupakan tanggung jawab bersama, antara orang tua, pendidik, pengasuh, masyarakat, dan pemerintah. Untuk itu kebersamaan, keselarasan, dan kemitraan dalam menanamkan nilai-nilai karakter sejak usia dini harus digalang dan dioptimalkan bersama.

Bagi orangtua diharapkan adanya kerjasama dalam menerapkan nilai-nilai karakter yang sudah dibiasakan di sekolah dapat diterapkan pula di rumah. Bagi masyarakat dan pemerintah diharapkan dukungan suasana yang kondusif bagi terbentuknya karakter anak dan bagi pendidik, pengasuh dan pengelola KB-TK Arrahman Islamic School diharapkan untuk dapat memperhatikan prinsip pendidikan karakter, kriteria guru dan kriteria sekolah agar pendidikan karakter dapat berhasil secara efektif dan efisien.

\section{PUSTAKA ACUAN}

A. Koesoema, Doni. 2007. Pendidikan Karakter: Strategi Mendidik Anak di Zaman Global. Jakarta: Grasindo.

Boedimansyah. 2010. Model Pendidikan Karakter. Bandung: Rosyda Karya.

Djamarah Bahri, Syaiful. (2000). Guru dan Anak Didik dalam Interaksi Edukatif. Jakarta: PT Rineka Cipta.

Jakarta: Indonesia Heritage Foundation. Pedoman Pendidikan Karakter pada Pendidikan Anak Usia Dini.

117 |Fikrah : P-ISSN : 2599-1671, E-ISSN : 2599-168X 
Fikrah : Journal Of Islamic Education, Vol 1 No. 2 Desember 2017

Koesoema. 2010. Pendidikan Karakter: Strategi Mendidik Anak di Zaman Global. Jakarta: PT. Grasindo.

Kaswardi. 1993. Pendidikan Nilai Memasuki Tahun 2000. Jakarta: PT. Grasindo.

Masitoh, Ocih Setiasih, Heny Djoehaeni. (2005). Pendekatan Belajar Aktif di Taman KanakKanak. Jakarta: Depdiknas.

Megawangi, R. 2004. Pendidikan Karakter, Solusi yang Tepat Untuk Membangun Bangsa.

Megawangi, R. 9 Pilar Karakter, Indonesia Heritage Foundation.

Mulyana, Rohmat. 2004. Mengartikulasikan Pendidikan Nilai. Bandung: Alfabeta.

Permendiknas RI No. 58 Tahun 2009, tentang Standar Pendidikan Anak Usia Dini.

Sjarkawi, 2006. Pembentukan Kepribadian Anak. Peran Moral, Intelekatual, Emosional, dan Sosial sebagai Wujud Integritas Membangun Jati Diri. Jakarta: PT. Bumi Aksara.

Sulhan, Najib. 2006. Pembangunan Karakter pada Anak: Manajemen Pembelajaran Guru Menuju Lembaga PAUD Efektif. Surabaya: Intelektual Club.

Suyata dan Darmiyati Zuchdi. 2007. "Ary Ginanjar Agustian dan Gerakan Pembaruan Pendidikan Karakter dengan Optimalisasi Kecerdasan Emosional Spiritual”. Pidato Promotor pada Pemberian Gelar Doctor Honoris Causa dalam Bidang Pendidikan Karakter kepada Ary Ginanjar Agustian. Yogyakarta: Universitas Negeri Yogyakarta.

Suyanto. 2009. Urgensi Pendidikan Karakter. Ditjen Pendas Kemendiknas.

Tilaar. 2002. Perubahan Sosial dan Pendidikan, Pengantar Pedagogik Transformative untuk Indonesia. Jakarta: PT. Grasindo.

Tilaar, H.A.R. 2007. Mengindonesia Etnisitas \& Identitas: Tinjauan dari Perspektif Ilmu Pendidikan Bangsa Indonesia, Jakarta: PT Pineka Cipta.

Thom, Markham. (2003). Project Based Learning Handbookfor Middle and High School Teachers. [Online]. Tersedia:http://www.amazon.com/Project-Based-LearningHandbook-StandardsFocused/dp/0974034304\#reader.html [23 Desember 2008].

Zuchdi, Darmiyati. 2009. Humanisasi Pendidikan: Menemukan Kembali Pendidikan yang Manusiawi. Jakarta: Bumi Aksara.

118 Fikrah : P-ISSN : 2599-1671, E-ISSN : 2599-168X 